\title{
MANAJEMEN PROMOSI BMT SYAHIDA IKALUIN DALAM MENINGKATKAN KEANGGOTAAN PRODUK SIMPANAN SYAHIDA
}

\section{Ririn Indah Lesatari}

Program Studi Perbankan Syariah, Fakultas Agam Islam, Universitas Nahdlatul Ulama Indoensia (UNUSIA)

Article Information

Informasi Artikel

Naskah diterima: 8 Juli 2019

Naskah direvisi: 15 Juni 2019

Naskah disetujui:

Agustus

Naskah dipublish

Oktober 2019

Kata Kunci

Manajement, BMT

Sahida, Simpanan

E-mail: $\underline{\text { rindahlestari12@gmail.com }}$

\section{Abstrak}

Tujuan penelitian ini adalah untuk mengetahui manajemen marketing dan strategi promosi BMT SYAHIDA IKALUIN dalam hal peningkatan jumlah anggota melalui produk simpanan syahida. Penelitian ini menyimpulkan bahwa strategi yang dilakukan oleh BMT SYAHIDA 5 IKALUIN adalah dengan cara segmentasi pasar yaitu melihat kebutuhan masyarakat ketika sudah ditemukan apa 5 yang dibutuhkan oleh masyarakat lalu BMT mengeluarkan produk yang dapat memenuhi kebutuhan tersebut. Penelitian ini menggunakan teknik analisis deskriptif kualitatif, yaitu prosedur penelitian yang menggunakan data atau lebih cenderung menggunakan analisis dengan pendekatan induktif.

\section{PENDAHULUAN}

Lembaga Keuangan Syariah (LKS) merupakan lembaga keuangan yang prinsip operasinya berdasarkan pada prinsip-prinsip syariah yang mana harus terhindar dari unsur riba, gharar, maisyir dan akad-akad yang bathil. Tujuan utama dalam pendirian lembaga kuangan syariah adalah untuk menunaikan perintah Allah dalam bidang ekonomi dan muamalah serta membebaskan masyarakat islam dari kegiatan-kegiatan yang dilarang oleh agama islam.

Keberadaan lembaga keuangan syariah khususnya sektor perbankan menempati posisi yang strategis dalam menghubungkan antara pihak yang kelebihan dana dengan pihak yang membutuhkan dana. Pada umumnya, produk-produk yang ditawarkan oleh lembaga keuangan syariah diantaranya produk penghimpunan dana (funding), produk penyaluran dana (financing) dan produk jasa (service). Produk penyaluran dana atau pembiayaan dapat dibedakan berdasarkan tujuan penggunaannya, yakni pembiayaan dengan prinsip jual-beli, pembiayaan dengan prinsip sewa, pembiayaan dengan prinsip bagi hasil dan pembiayaan dengan akad pelengkap. 
Baitul Mal wa Tamwil (BMT) merupakan bagian dari lembaga keuangan syariah. BMT adalah balai usaha mandiri terpadu yang isinya berintikan bayt al-mal wa at-tamwill . BMT juga merupakan lembaga keuangan mikro yang dioperasikan dengan prinsip bagi hasil, menumbuh kembangkan bisnis usaha mikro dalam rangka mengangkat derajat dan martabat serta membela kepentingan kaum fakir miskin. Ditumbuhkan atas prakarsa dan modal awal dari tokoh-tokoh masyarakat setempat dengan berlandaskan pada sistem ekonomi yang salaam keselamatan (bertindak keadilan), kedamaian dan kesejahteraan².

BMT secara konseptual memiliki dua fungsi, yaitu bait at-tamwil (bait artinya rumah, at-tamwil artinya pengembangan harta) dan bait al-mal (bait artinya rumah, almal artinya harta), fungsi BMT sebagai bait at-tamwil adalah melakukan kegiatan pengembangan usaha-usaha produktif dan investasi dalam meningkatkan kualitas ekonomi pengusaha mikro dan kecil terutama dengan mendorong kegiatan menabung dan menunjang pembiayaan kegiatan ekonominya, sedangkan fungsi BMT sebagai bait al-mal adalah menerima titipan dana zakat, infaq dan sedekah serta mengoptimalkan distribusinya sesuai dengan peraturan dan amanahnya ${ }^{3}$,

BMT sebagai lembaga keuangan mikro dapat membantu dalam hal permodalan dengan prosedur dan persyaratan permohonan kredit atau pembiayaan yang lebih mudah dan tidak begitu rumit bila dibandingkan dengan mengajukan pembiay aan kepada BPR atau BPRS dan Perbankan yang menerapkan prinsip kehati-hatiannya dalam memberikan pembiayaan. Dengan begitu, adanya BMT sangat membantu masyarakat menengah ke bawah dalam mengembangkan usahanya. Selain lembaga keuangan mikro, BMT juga merupakan salah satu lembaga keuangan islam yang berbadan hukum koperasi dengan didasarkan atas prinsip bagi hasil, jual beli dan titipan (wadiah $)^{4}$. BMT dapat didirikan dalam bentuk KSM (kelompok swadaya masyarakat) atau koperasi. Penggunaan badan hukum KSM dan koperasi untuk BMT ini disebabkan karena BMT tidak termasuk kepada lembaga keuangan formal yang dijelaskan UU No. 7 Tahun 1992 dan UU No.

\footnotetext{
${ }^{1}$ AhmadHasan Ridwan, Manajemen Baitul Mal wa Tamwil, (Jakarta: CV Pustaka Setia, 2013), h.23.

${ }^{2}$ M. Nur Rianto Al-Arif, Dasar-Dasar Ekonomi Islam, (Surakarta: Era Adicitra Intemedia, 2011), h. 377.

${ }^{3}$ M. Amin Aziz, Pedoman Pendirian BMT(Baitul Maal wat Tamwil), (Jakarta: Pinbuk Press, 2004), h. 1.

${ }^{4}$ Nurul Huda dan Muhammad Haykal, Lembaga Keuangan Islam: Tinjauan Teoritis dan Praktis, (Jakarta:Kencana, 2010), h. 363.
} 
10 Tahun 1998 tentang perbankan yang dapat dioperasikan untuk menghimpun dan menyalurkan dana masyarakat ${ }^{5}$.

Perkembangan BMT di Indonesia berdampak terhadap minat para praktisi untuk mendirikan BMT, termasuk didalamnya praktisi dari Universitas Islam Negeri Syarif Hidayatullah Jakarta yang dikenal dengan Ikatan Alumni UIN dengan mendirikan sebuah lembaga keuangan mikro syariah yaitu BMT SYAHIDA IKALUIN. Sama seperti lembaga keuangan syariah lainnya, BMT SYAHIDA juga menawarkan produk penghimpunan dana (Funding), penyaluran dana (financing) dan jasa (service). Tetapi dalam sistem kerjanya BMT SYAHIDA tidak hanya terfokus pada pembiayaan saja, BMT SYAHIDA juga berupaya untuk mengembangkan UMKM, caranya adalah dengan memberikan pelatihan-pelatihan pada usaha mikro yang baru berjalan, agar terciptanya kelompok usaha yang kreatif, inovatif, serta berjiwa islami dan entrepreneur yang mempunyai kepedulian juga tanggung jawab.

BMT SYAHIDA IKALUIN Ciputat adalah salah satu dari sekian banyak BMT di Indonesia yang sedang berkembang, yang saat ini sudah memiliki aset senilai Rp 1.218.000.000. Di dalam perkembangannya, BMT SYAHIDA IKALUIN sudah banyak mengeluarkan produk. Salah satu produknya adalah bagian dari jenis produk simpanan yaitu produk simpanan syahida (Si Syahid). Produk ini merupakan produk tabungan yang bisa simpan-tarik kapan saja pada hari efektif kerja. Produk ini cukup diminati oleh sebagian masyarakat, salah satu keunggulannya adalah karena dapat simpan-tarik kapan saja tanpa adanya ketentuan waktu pengambilan.

BMT dalam operasionalnya juga membutuhkan strategi pemasaran, sama halnya seperti perbankan. Tujuan dari strategi ini adalah untuk kelangsungan hidup dan berkembangnya BMT. Secara konsep, BMT memang menghendaki adanya bebas riba dan juga penerapan strategi promosinya sesuai dengan syariah islam sehingga terciptanya keadilan. Hal demikian mengharuskan manajeman melakukan strategi khusus untuk mempertahankan keunggulan kompetitif yakni merujuk pada kemampuan sebuah organisasi untuk memformulasikan strategi yang menempatkanny a pada suatu porsi yang menguntungkan berkaitan dengan perusahaan.Keunggulan kompetitif juga

\footnotetext{
5 Dzajuli dan Yadi Janwari, Lembaga-lembaga Perekonomian Umat, (Jakarta: PT. Raja Gra findo Persada, 2002), h. 187.
} 
berarti kumpulan strategi untuk menentukan keunggulan suatu perusahaan dari persaingan dengan perusahaan lainnya ${ }^{6}$.

Strategi marketing didalamnya terdapat tiga medan pertempuran yang harus dimenangkan, pada aspek strategis, yaitu segmentasi pasar (segmatation), target pasar yang tepat (targetting) dan penentuan posisi (positioning) haruslah lebih baik dalam rangka memenangkan perang pemikiran dalam hal bagaimana untuk menarik minat nasabah/anggota dalam upaya meningkatkan jumlah anggota/nasabah tersebut. Aspek taktik dalam berdagang mesti memperhatikan aspek-aspek penting yaitu, differentation (keunikan) dari sebuah produk agar berbeda dengan produk-produk lainnya, juga dengan marketing mix yang sering dikenal istilah 4P (Product, price, place dan promotion) dan selling, yaitu untuk memenangkan penjualan serta persaingan pasar.

Memenangkan, mengembangkan dan mempertahankan persaingan pasar agar penjualan atau minat angota/nasabah tidak menurun akibat ketidakpuasan anggota/ nasabah, maka lembaga mencoba memecahkan permasalahan dengan merencanakan manajeman promosi yang didalamnya terdapat strategi-strategi yang dapat dilakukan lembaga serta cocok untuk dijalankan. Kebutuhan informasi harus segera dipenuhi dengan melakukan penelitian agar lembaga dapat mengambil tindakan-tindakan yang perlu sebagai strategi promosi juga bisa untuk perbaikan produk demi meningkatkan kinerja perusahaan.

\section{METODOLOGI PENELITIAN}

Jenis penelitian yang digunakan dalam penelitian ini adalah penelitian kualitatif. Metode kualitatif adalah penelitian secara ilmiah yang bertujuan untuk memahami suatu fenomena dalam konteks sosial secara alamiah dengan mengedepankan proses interaksi komunikasi yang paling mendalam antara peneliti dan fenomena yang diteliti. Dalam penelitian ini, pengumpulan data dilakukan pada natural setting (kondisi yang alamiah), sumber data primer. dan teknik pengumpulan data menggunakan tiga teknik yaitu observasi (berperanserta aktif dalam pengamatan lapangan), in depth interview (wawancara mendalam), dan dokumentasi.

\footnotetext{
${ }^{6}$ Da vid Hunger dan Thomas Wheelen,Manajemen Strategis, (Yogyakarta: Penerbit Andi, 2003), h. 13.
} 


\section{KAJIAN TEORI}

1. Lembaga Keuangan

Lembaga keuangan adalah semua badan yang kegiatannya di bidang keuangan, melakukan penghimpunan dan penyaluran dana kepada masyarakat terutama guna membiayai investasi perusahaan. Meski dalam peraturan tersebut lembaga keuangan diutamakan untuk membiayai investasi perusahan namun tidak berarti membatasi kegiatan pembiayaan lembaga keuangan.Dalam kenyataannya, kegiatan u sahalembaga keuangan bisa diperuntukan bagi investasi peru sahaan, kegiatan konsumsi dan kegiatan distribusi barang dan jasa ${ }^{7}$.

Berdasarkan pengertian lain yakni menurut Dahlan Siamat yang dikutip oleh Andri Soemitra, lembaga keuangan adalah badan usaha yang kekayaannya terutama dalam bentuk aset keuangan atau aset tagihan (claims) dibandingkan dengan asset nonfinansial dan riil. Lembaga keuangan memberikan pembiayaan/kredit kepada nasabah dan menanamkan dananya dalam surat-surat berharga. Disamping itu, lembaga keuangan juga menawarkan berbagai jasa keuangan, antara lain: menawarkan berbagai jenis skema tabungan, proteksi asuransi, program pensiun, penyediaan sistem pembayaran dan mekanisme transfer dana.

Lembaga keuangan juga memiliki pengertian setiap perusahaan yang bergerak dibidang keuangan, menghimpun dana menyalurkan dana atau kedua-duanya. Artinya kegiatan yang dilakukan lembaga keuangan selalu berkaitan dengan keuangan, apakah kegiatannya hanya

menghimpun dana atau hanya menyalurkan dana atau kedua-duanya menghimpun dan menyalurkan dana ${ }^{8}$.

Dengan demikian dapat disimpulkan bahwa lembaga keuangan adalah setiap perusahaan yang kegiatan usahanya berkaitan dengan bidang keuangan, kegiatan usahanya bisa menghimpun dana atau menyalurkan dana juga bisa keduanya.

2. Lembaga Keuangan Syariah dan Lembaga Keuangan Non Syariah

\footnotetext{
${ }^{7}$ Andri Soemitra, Bank \& Lembaga Keuangan Syariah, (Jakarta: Kencana, 2016), h. 25.

${ }^{8}$ Andri Soemitra, Bank \& Lembaga Keuangan Syariah,(Jakarta: Kencana, 2016),h. 26.
} 
Perbedaan antara lembaga keuangan syariah dengan lembaga keuangan konvensional, akan diambil contoh mendasar mengenai perbedaan bank syariah dengan bank konvensional, yaitu sebagai berikut:

a) Akad dan Aspek Legalitas

Akad yang digunakan dalam lembaga keuangan syariah memiliki konsekuensi duniawi dan ukhrawi karena akad yang dilakukan berdasarkan hukum islam. Setiap akad dalam lembaga keuangan syariah, baik dalam hal barang, pelaku transaksi, maupun ketentuan lainnya harus memenuhi ketentuan akad.Penyelesaian perselisihan antara lembaga dan nasabah pada lembaga keuangansyariah berbeda dengan lembaga keuangan konvensional. Kedua pihak dalam lembaga keuangan syariah tidak menyelesaikannya di pengadilan negeri, tapi menyelesaikannya sesuai tata cara hukum menteri syariah dan diselenggarakan di Pengadilan Agama . Lembaga yang mengatur hukum menteri dan atau berdasarkan prinsip syariah di Indonesia dikenal dengan nama Badan Arbitrase Muamalah Indonesia (BAMUI) yang didirikan secara bersama oleh Kejaksanaan Agung RI dan Majelis Ulama Indonesia (MUI). Namun, sampai saat ini penyelesaian pertikaian masih dilakukan di Pengadilan Negeri.

b) Struktur Organisasi

Lembaga keuangan syariah memiliki struktur yang sama dengan lembaga keuangan konvensional. Misalnya dalam hal komisaris dan direksi, tetapi unsur yang dapat menbedakan antara lembaga keuangan syariah dengan lembaga keuangan konvensional adalah keharusan adanya DPS yang berfungsi mengawasi opersional bank dan produk-produknya agar sesuai dengan garis-garis syariah.

c) Bisnis dan Sektor Usaha yang dibiayai

Bisnis dan usaha yang dilakukan lembaga keuangan syariah tidak terlepas dari ketentuan syariah.Hal tersebut menyebabkan bank syariah tidak dibolehkan membiayai usaha yang mengandung unsur yang diharamkan seperti maisyir, gharar, riba (MAGHRIB), contoh industrinya misalkan industri rokok, industri minuman keras dan industri lainnya yang masih diperdebatkan kehalalannya.Terdapat sejumlah batasan dalam hal pembiayaan. Tidak semua proyek atau objek pembiayaan dapat didanai melalui dana lembaga keuangan syariah, namun juga harus sesuai kaidah-kaidah syariah.

d) Lingkungan dan Budaya kerja 
Lembaga keuangan syariah selayaknya memiliki lingkungan kerja yang mengandung nilai-nilai syariah. Dalam etika, misalnya sifat amanah dan shiddiq, harus melandasi setiap karyawan sehingga tercermin integritas eksekutif muslim yang baik. Selain itu, karyawan lembaga keuangan syariah harus professional (fathonah) mampu melaksankan tugas secara teamwork dimana informasi merata di seluruh fungsional organisasi (tabligh). Dalam hal reward dan punishment, diperlukan prinsip keadilan yang sesuai dengan syariah.

3. Akad-akad yang digunakan pada Produk Simpanan

Pada umumnya dalam produk simpanan, lembaga keuangan hanya menggunakan dua akad yaitu akad wadiah dan mudharabah.

a) Wadiah

Al-wadiah dapat diartikan sebagai titipan murni dari satu pihak ke pihak lain, baik individu atau badan hukum, yang harus di jaga dan dikembalikan kapan saja si penitip menghendaki ${ }^{9}$. Akad wadiah terbagi menjadi dua yaitu, wadiah yad al-amanah dan wadiah yad ad-dhamanah.wadiah yad al-amanah adalah pihak yang menerima tidak boleh menggunakan dan memanfaatkan harta yang dititipikan akan tetapi membebankan biaya kepada pihak yang menitipi sebagai biaya penitipan. Sedangkan wadiah yad ad-dhamanah adalah penerima titipan dapat menggunakan harta tersebut dalam aktivitas perekonomian tertentu dengan izin dari pemberi titipan dengan syarat ia menjamin akan mengembalikan aset tersebut secara utuh dan ia bertanggung jawab atas segala kehilangan atau kerusakan yang terjadi pada harta tersebut ${ }^{10}$.

b) Mudharabah

Mudharabah berasal dari kata dharb, berarti memukul atau berjalan. Pengertian memukul atau berjalan ini lebih tepatnya adalah proses sesorang memukulkan kakinya dalam menjalankan usaha. Secara teknis, al-mudharabah adalah akad kerjasama antara dua pihak dimana pihak pertama (shohibul maal) menyediakan seluruh (100\%) modal, sedangkan pihak lainnya menjadi pengelola.Keuntungan usaha secara mudaharabah

\footnotetext{
${ }^{9}$ Nurul Ichsan Hasan, Perbankan Syariah (Sebuah Pengantar), (Ciputat: GP Press Group, 2014), h. 123.

${ }^{10}$ Nurul Ichsan Hasan, Perbankan Syariah (Sebuah Pengantar), (Ciputat: GP Press Group, 2014), h. 126-127.
} 
dibagi menurut kesepakatan yang dituangkan dalam kontrak, sedangkan apabila rugi ditanggung oleh pemodal selama kerugian itu bukan akibat kelalaian si pengelola ${ }^{11}$.

4. Manajemen Marketing

Aktivitas manajemen secara umum dalam organisasi diarahkan untuk mencapai tujuan organisasi secara efektif dan efisien. Manajemen adalah proses bekerja sama antara individu dan kelompok serta sumber daya lainnya dalam mencapai tujuan, organisasi adalah bagian dari aktivitas manajemen. Dengan kata lain, aktivitas manajerial hanya ditemukan dalam wadah sebuah organisasi, baik organisasi bisnis, sekolah dan juga lainnya ${ }^{12}$.

Kegiatan manajemen tegasnya selalu saja melibatkan alokasi dan pengawasan dana, sumber daya manusia dan fisik untuk mencapai tujuan yang ditetapkan. Sebagai ilmu, manajemen memilki pendekatan sistematik yang selalu digunakan dalam memecahkan masalah. Pendekatan manajemen bertujuan untuk menganalisis proses, membangun kerangka konseptual kerja, mengidentifikasi prinsip-prinsip yang mendasarinya dan membangun teori manajemen dengan menggunakan pendekatan tersebut. Karena itu manajemen adalah proses universal berkenaan dengan adanya jenis lembaga, berbagai posisi dalam lembaga, atau pengalaman pada lingkungan yang beragam luasnya antara berbagai persoalan kehidupan.

Fungsi-fungsi manajemen adalah sebagai berikut: a. Perencanaan (Planning) Perencanaan adalah penentuan secara matang dan cerdas tentang apa yang akan dikerjakan dimasa yang akan datang dalam rangka mencapai tujuan. b. Pengorganisasian (Organizing) Pengorganisasian adalah pembagian pekerjaan yang direncanakan untuk diselesaikan oleh anggota kelompok pekerjaan, penentuan hubungan-hubungan pekerjaan diantara mereka dan pemberian lingkungan pekerjaan yang seharusnya.c. Penggerakkan(Actuating) Penggerakkan merupakan hubungan erat antara aspek-aspek individual yang ditimbulkan dari adanya pengaturan terhadap bawahan untuk dapat dimengerti dan pembagian kerja yang efektif dan efisien untuk mencapai tujuan perusahaan yang nyata. Pengertian ini memberikan kejelasan bahwa penggerakan adalah kegiatan untuk mengarahkan orng lain agar suka dan dapat bekerja

\footnotetext{
${ }^{11}$ Nurul Ichsan Hasan, Perbankan Syariah (Sebuah Pengantar), (Ciputat: GP Press Group, 2014), h. 133.

${ }^{12}$ Sya faruddin, Manajemen Lembaga Pendidikan Islam, (Jakarta:Ciputat Press, 2015), h. 41.19
} 
dalam upaya pencapaian tujuan. d. Pengendalian (Controling) Secara etimologis “controlling" lazimnya diterjemahkan dengan pengendalian.Pengawasan (controlling) adalah suatu usaha untuk meneliti kegiatan-kegiatan yang telah dilaksanakan.Pengawasan berorientasi pada objek yang dituju dan merupakan alat untuk menyuruh orang-orng bekerja mencapai sasaran yang ingin dicapai ${ }^{13}$.

5. Marketing

Pemasaran (marketing) adalah sistem keseluruhan dari kegiatan usaha yang ditujukan untuk merencanakan, menentukan harga, mempromosikan dan mendistribusikan barang dan jasa yang dapat memuaskan kebutuhan kepada pembeli yang ada maupun pembeli potensial ${ }^{14}$.

Secara spesifik pengertian pemasaran bagi lembaga keuangan adalah:

1. Mengidentifikasi pasar yang paling menguntungkan sekarang dan masa yang akan datang.

2. Menilai kebutuhan nasabah atau anggota saat ini dan masa yang akan datang.

3. Menciptakan sasaran pengembangan bisnis dan membuat rencana untuk mencapai sasaran tersebut.

4. Promosi untuk mencapai sasaran.

Didalam pemasaran terdapat bauran pemasaran yang merupakan kegiatan pemasaran yang dilakukan secara terpadu, maksudnya kegiatan yang dilakukan secara bersama diantara elemen-elemen yang ada dalam bauran pemasaran itu sendiri. Untuk itu, ada empat konsep yang harus dilibatkan dalam pemasaran tersebut yaitu:

\section{Produk (Product)}

Produk secara umum diartikan sebagai suatu yang dapat memenuhi kebutuhan dan keinginan konsumen. Produk yang diinginkan konsumen baik yang berwujud maupun tidak berwujud adalah produk yang berkualitas tinggi. Artinya produk yang dikeluarkan oleh lembaga/perusahaan memiliki nilai yang lebih dibandingkan produk pesaing. Produk yang berkualitas tinggi yang berhasil diciptakan oleh lembaga/perusahaan akan memberikan keuntungan baik dalam jangka pendek maupun jangka panjang.

\section{Harga (Price)}

\footnotetext{
${ }^{13}$ Marno dan Trio Supriyanto, Manajemen dan Kepemimpinan Pendidikan Islam, (Bandung: PT Reflika Aditama, 2008),h. 24.

${ }^{14}$ Muhammad, Manajemen Bank Syariah, (Yogyakarta: UPP AMP YKPN, 2002), h. 194.
} 
Harga merupakan aspek penting dalam kegiatan marketing, karena mengingat harga sangat menentukan laku atau tidaknya produk lembaga/perusahaan. Dalam menetapkan harga haruslah dilakukan setelah memonitoring harga yang ditetapkan pesaing agar harga yang ditentukan kompetitif.

\section{Saluran Distribusi (Place)}

Distribusi merupakan kegiatan ekonomi yang menjembatani kegiatan produksi dan konsumsi. Berkat distribusi, barang dan jasa sampai ke tangan konsumen. Dala m sektor jasa distribusi didefinisikan sebagai setiap sasaran yang meningkatkan keberadaan atau kenikmatan suatu jasa yang menambah penggunanya atau pendapatan dari penggunanya baik dengan mempertahankan pemakai yang ada maupun meningkatkan nilai kegunaannya diantara pemakai yang ada ataupun menarik pemakai yang baru.

\section{Promosi (Promotion)}

Promosi merupakan kegiatan yang ditujukan untuk mempengaruhi konsumen agar mereka dapat menjadi kenal akan produk yang ditawarkan oleh perusahaan kepada mereka kemudian mereka akan menjadi senang lalu membeli produk yang ditawarkan tesebut.

\section{PROFIL BMT SYAHIDA IKALUIN}

Baitul Mal berasal dari bahasa Arab “bait” yang berarti rumah. Dan “Al-Mal” yang berarti harta. Jadi, secara etimologi, Baitul Mal berarti rumah untuk mengumpulkan harta sedangkan SYAHIDA yang merupakan kepanjangan dari Syarif Hidayatullah, karena BMT SYAHIDA berada di dalam lingkungan UIN. Sedangkan IKALUIN juga merupakan kepanjangan dari Ikatan Alumni UIN, karena sebagian besar pengurus BMT SYAHIDA berasal dari UIN. Adapun secara terminologis, Baitul Mal diartikan sebagai tempat untuk menyimpan dan mengelola segala macam harta. Baitul Mal wat Tamwil Syarif Hidayatullah disingkat BMT SYAHIDA merupakan lembaga keuangan mikro syariah dengan badan hukum koperasi. BMT SYAHIDA digagas oleh ikatan alumni UIN atau disingkat IKALUIN Syarif Hidayatullah Jakarta bersama beberapa dosen ahli ekonomi islam dan keuangan UIN Syarif Hidayatullah Jakarta pada bulan Maret sampai dengan Mei 2014.

Seiring dengan perkembangan ekonomi dan keuangan syariah di Indonesia dan di berbagai belahan dunia saat ini, kami sebagai alumni UIN Syarif Hidayatullah merasa terpanggil untuk turut berpartisipasi dalam merespon fenomena ini. Bentuk 
upaya konkrit yang dilakukan adalah dengan mendirikan lembaga keuangan mikro syariah dalam wadah koperasi syariah BMT yang selanjutnya disebut BMT SYAHIDA IKALUIN. Sejak pendiriannya pada bulan Mei 2014 BMT SYAHIDA IKALUIN telah menyelenggarakan RAT-nya yang pertama untuk menyampaikan kinerja BMT pada kondisi yang paling awal. Dengan upaya dan kesungguhan dari keseluruhan tim pengurus, pengelola, pengawas dan konsultan, alhamdulillah hingga saat ini BMT SYAHIDA IKALUIN masih eksis keberadaannya dan tetap menyelenggarakan RAT secara rutin setiap tahunnya. Perlahan namun pasti BMT SYAHIDA terus bergulir dalam upaya memberdayakan ekonomi masyarakat didalam maupun di sekitar lingkungan kampus. TEPAT PADA TANGGAL 13 Mei 2014 Baitul Mal wa Tamwil Syarif Hidayatullah atau BMT SYAHIDA mendapatkan badan hukum secara resmi dari Dinas Koperasi dan UKM kota Tangerang Selatan dengan keputusan Nomor: 518/163/BH/XI.08/kop.UKM serta diresmikan langsung oleh Walikota Tangerang Selatan, Airin Rachmi Diany pada tanggal 25 Mei 2014.

\section{Produk BMT SYAHIDA IKALUIN}

\section{Prinsip Wadiah Yadh Dhomanah}

Merupakan simpanan dengan akad titipan (wadiah) dimana BMT selaku pemegang amanah memiliki hak untuk memanfaatkan dana tersebut dalam usahanya dengan izin pemilik tanpa kewajiban melakukan bagi hasil. Akan tetapi, dengan kebijakan manajeman BMT boleh memberikan bonus kepada pemilik harta. Simpanan ini tidak dikenakan biaya administrasi. Produk-produk himpunan pada BMT SYAHIDA IKALUIN diantaranya: 1) Simpanan Syahida (Si Syahid) Merupakan produk tabungan yang bisa simpan-tarik kapan saja pada hari dan jam kerja efektif kerja dengan prinsip syariah dan mudah. 2) Simpanan Pendidikan (Si Cerdas) Merupakan simpanan wadiah untuk kebutuhan wisuda dan semester, 3) Simpanan Idul Fitri (Si Fitri) Merupakan simpanan untuk persiapan hari raya Idul Fitri, simpanan ini disimpan setiap minimal satu bulan sekali dan hanya bisa diambil menjelang hari raya Idul Fitri. 4) Simpanan Aqiqah dan Qurban (Si Aqur) Merupakan simpanan untuk melaksanakan ibadah aqiqah dan qurban, simpanan ini bisa dilakukan setiap satu bulan sekali dan hanya bisa diambil menjelang hari raya qurban atau pelaksanaan aqiqah. 5) Simpanan Umroh dan Haji (Si Mabrur) Merupakan simpanan untukmelaksanakanibadah haji dan umroh, simpanan ini merupakan simpanan dengan akad wadiah. 6) Baitul Maal 
Syahida Adalah penyimpanan dan penyaluran ZISWAF (Zakat, Infaq, Shadaqah dan Wakaf).

\section{Prinsip Bagi Hasil Mudharabah}

Merupakan simpanan dalam jangka waktu tertentu dengan menggunakan akad mudharabah dimana mitra sebagai shahibul maal (investor) mempercayakan kepada BMT sebagai mudharib untuk mengusahakan dananya pada sektor usaha yang sudah ditentukan oleh mitra (mudharabah muqayyadah) ataupun usaha-usaha lainnya yang dimilki oleh BMT (mudharabah mutlaqah). Keuntungan dari usaha tersebut dibagi hasilkan sesuai nisbah yang disepakati dan kerugian 100\% menjadi tanggungan shahibul maal.

\section{MANAJEMEN MARKETING BMT SYAHIDA IKALUIN DALAM MENINGKATKAN JUMLAH ANGGOTA}

Manajemen marketing yang dilakukan BMT SYAHIDA IKALUIN sama halnya dengan yang dilakukan lembaga keuangan syariah pada umumnya yaitu dengan memanfaatkan media untuk menyebarluaskan informasi terkait BMT. Karena sekarang adalah zaman now / zaman millenial jadi harus memberdayakan media terutama dari web dan instagram, namun disini yang lebih sering digunakan BMT adalah instagram. Selain itu juga dibantu oleh media cetak melalui brosur. Penyebaran brosur ke mahasiswa juga berkeliling di sekitar daerah Ciputat yang pasti tidak jauh jangkauannya dari lokasi kantor BMT SYAHIDA IKALUIN, brosur ini pun punya target bahwasannya minimal satu bulan harus habis ${ }^{15}$.

Dalam hal meningkatkan jumlah anggota, manajeman marketing BMT tak terlepas dari pengaruh besar produk simpanan syahida. Yang dinilai cukupefektif untuk meningkatkan jumlah anggota, karena dapat dilihat sendiri bahwa jumlah anggota terbanyak dari masing-masing produk yang dikeluarkan BMT SYAHIDA IKALUIN adalah pada produk simpanan syahida. Minat masyarakat untuk menabung pun cukup banyak, alasan mereka menabung pun berbagai macam ada yang sengaja menabung hanya untuk menyisihkan uang agar ketika mereka ada keperluan mendadak dapat terpenuhi, juga ada yang manabung sebagai persiapan dana yang digunakan untuk pulang kampung ketika hari raya tiba.

\footnotetext{
${ }^{15}$ Wa wancara dengan Account Officer Sulfi Afria di S.Hum, hari Ka mis 02 Mei2019 pukul 16.40 wib.
} 
Banyaknya anggota pada produk simpanan syahida (tabungan) ini juga disebabkan karena faktor keunggulan yang ada pada produk tersebut, antara lain, BMT lebih pro aktif kepada anggota, BMT berlandaskan syariah dan saldo minimal yang ditetapkan jauh lebih rendah dari lembaga keuangan lainnya. Keunggulan lainnya yaitu anggota produk simpanan syahida jika sewaktu-waktu memerlukan dana maka dapat mengambil dana dalam tabungannya tersebut kapan saja pada jam operasional BMT SYAHIDA IKALUIN, dari keunggulan ini lah maka muncul banyak minat masyarakat menjadi bagian dari anggota BMT SYAHIDA IKALUIN khususnya pada produk simpanan syahida.

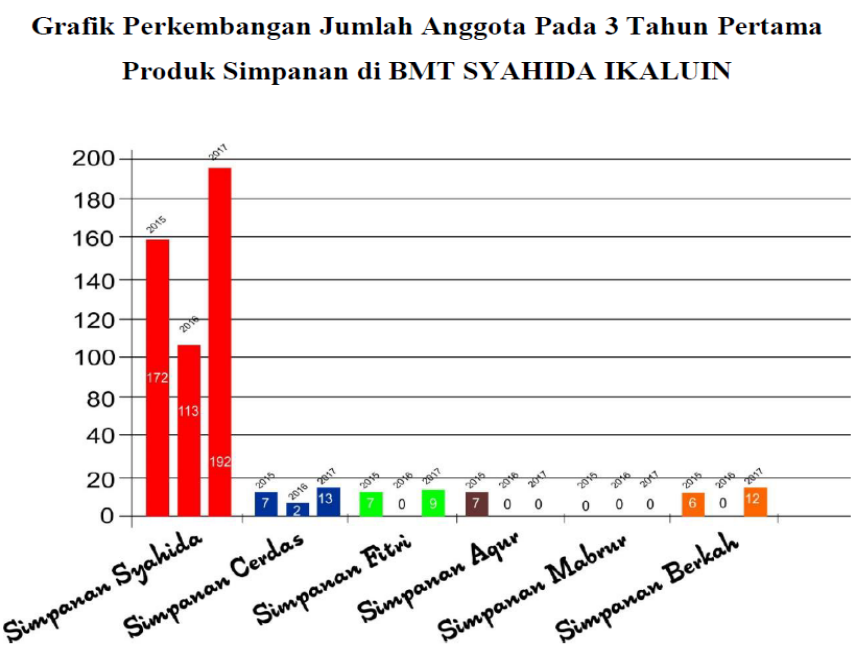

1. Prosedur pengajuan untuk menjadi anggota pada Produk Simpanan Syahida

Masyarakat yang akan menjadi calon anggota ataupun mitra pada produk Simpanan Syahida dapat datang langsung ke kantor BMT SYAHIDA IKALUIN dan mengajukan permohonan untuk bergabung, lalu memenuhi persyaratan yang di tentukan:

a. Mengisi formulir pembukaan rekening simpanan

b. Fotocopy identitas diri, misalnya KTP

c. Mengisi formulir kesediaan menjadi anggota

d. Membayar biaya buku tabungan sebesar Rp 10.000,-

e. Menyetorkan setoran awal sebesar Rp 50.000,-

Jika semua persyaratan telah dipenuhi maka yang bersangkutan resmi menjadi anggota BMT SYAHIDA IKALUIN pada Produk Simpanan Syahida.

2. Manajemen marketing BMT SYAHIDA IKALUIN 
Berhasil atau tidaknya sebuah lembaga/perusahaan sangat bergantung pada bagaimana strategi pemasarannya. Penjualan merupakan faktor penting agar perusahaan/lembaga dapat tetap berdiri, tanpa adany a penjualan suatu perusahaan dapat mengalami kerugian karena minimnya sumber daya. Strategi marketing BMT SYAHIDA IKALUIN adalah sebagai berikut:

a. Segmentasi pasar

Hal y ang paling utama dalam melakukan pemasaran adalah riset pasar (research market). Dengan melakukan hal ini, BMT dapat menemukan dan memilih segmentasi pasar yang tepat sehingga produk yang dikeluarkan dapat bersaing dan berkembang pada pasar tersebut. Sesuai dengan pernyataan Bapak Ir. Boni Faisal pada wawancara hari Jum'at 03 Mei 2019 pukul 14.50 bahwa BMT SYAHIDA IKALUIN terlebih dahulu melihat kebutuhan masyarakat, lalu berdasarkan kebutuhan tersebut dicarikanlah solusi oleh pihak BMT.

b. Promosi

Setelah melakukan riset pasar, maka langkah berikutnya adalah melakukan promosi. Promosi sifatnyajuga tak kalah penting karena jika cara mempromosikan baik dan dapat diterima masyarakat maka hasilnya pun akan ikut baik. Promosi yang dilakukan berbagai macam media, diantaranya:.

a) Media cetak

Media cetak yang menunjang promosi yaitu berupa brosur, menyebarkan brosur merupakan media informasi dan promosi yang cukup sederhana, brosur disebarkan kepada masyarakat sekitar lokasi BMT SYAHIDA IKALUIN khususnya para civitas akademika UIN Syarif Hidayatullah (mahasiswa, dosen dan karyawan), sekitar pasar fatahillah dan parkiran motor dengan jumlah brosur 50 buah disetiap tempat dan hal ini dilakukan 2 bulan sekali. Didalam brosur juga diterangkan mulai dari profil BMT SYAHIDA IKALUIN itu sendiri, visi \& misi, prosedur manjadi anggota, berbagai jenis dan macam produk-produk yang dikeluarkan BMT untuk memenuhi kebutuhan masyarakat juga struktur organisasi dan alasan mengapa masyarakat harus memilih BMT SYAHIDA, dan juga pastinya brosur ini dikemas sedemikian mungk in sehingga mampu menarik perhatian masyarakat bahkan membuat masyarakat dapat bergabung menjadi aggota serta mitra dari BMT SYAHIDA IKALUIN.

b) Media sosial 
Promosi menggunakan media sosial yaitu memanfaatkan fasilitas perkembangan zaman yang ada, karena sekarang merupakan zaman milenial maka BMT SYAHIDA juga tidak mau ketinggalan, juga mempromosikan lewat web dan Instagram, walaupun yang lebih sering digunakan adalah lewat instagram. Kontenkonten yang dibagikan juga telah dikemas semenarik mungkin agar menarik perhatian netizen untuk membaca konten promosi yang dibuat dan dibagikan.

c) Penjualan Pribadi

Promosi dengan sistem ini banyak dilakukan pada awal berdirinya BMT, dengan adanya penjualan yang bersifat langsung, agar calon anggota dapat lebih mengetahui secara mendalam tentang produk yang dimiliki oleh BMT, karena segala permasalahan yang menghalangi minat anggota untuk menabung dapat langsung dicarikan jalan keluarnya oleh karyawan BMT yang bertugas. Dengan demikian eksistensinya BMT sering dilakukan oleh anggota dengan sistem dari mulut ke mulut, promosi mulut ke mulut ini juga dilakukan para anggota BMT SYAHIDA IKALUIN dengan cara juga menawarkan produk-produk BMT kepada saudara, tetangga, juga keluarga dan strategi ini di pandang cukup strategis juga sangat efektif.

c. Menjalin hubungan baik dengan anggota

Anggota adalah aset yang berharga bagi BMT. Oleh karena itu, pihak BMT hendaknya selalu memberikan pelayanan yang terbaik juga menjalin hubungan yang baik dengan anggota. Ini merupakan implementasi dari Hablum minannas salah satu keharusan seorang muslim yaitu menjalin hubungan baik dengan manusia.

Ayat Al-Qur'an yang berkaitan dengan hal ini adalah Q.S. Al-Anfal ayat 1 Artinya: "...oleh sebab itu bertakwalah kepada Allah dan perbaikilah hubungan diantara sesamamu dan taatlah kepada Allah dan Rasul-Nya jika kamu adalah orangorang yang beriman".

\section{STRATEGI PROMOSI PRODUK SIMPANAN SYAHIDA DI BMT SYAHIDA}

\section{IKALUIN}

Produk simpanan syahida mulai diperkenalkan oleh BMT SYAHIDA IKALUIN kepada masyarakat sejak diresmikannya BMT SYAHIDA IKALUIN tepat pada tanggal 25 Mei 2014.30 Hadirnya produk simpanan syahida semata-mata adalah untuk mengajak masyarakat agar gemar menabung, menyisihkan sebagian uangnya untuk dapat di tabungkan. Jumlah anggota simpanan syahida cukup banyak bahkan 
menempati rating teratas jumlah anggota terbanyak diantara jumlah anggota produkproduk BMT SYAHIDA IKALUIN lainnya, penambahan anggota produk simpanan syahida ini pun berkisar 3-4 orang perminggunya ${ }^{16}$.

Strategi promosi merupakan cara jitu untuk menarik minat masyarakat. Jika strateginya bagus sangat besar kemungkinan untuk mencapai tujuan perusahaan/lembaga. BMT SYAHIDA IKALUIN dalam menjalankan operasionalnya didukung dengan strategi salah satunya adalah strategi promosi. Strategi promosi ini digunakan untuk memasarkan bahkan memperkenalkan produk-produk yang dimiliki oleh BMT SYAHIDA IKALUIN ke masyarakat khususnya para civitas akademika UIN Syarif Hidayatullah yang meliputi golongan mahasiswa, dosen maupun karyawannya.

Mengacu pada landasan teori, bahwasannya strategi promosi BMT SYAHIDA IKALUIN tak jauh berbeda dengan strategi yang dilakukan oleh perusahaan atau lembaga pada umumnya. Dari pengertiannya strategi promosi adalah upaya yang di lakukan untuk memasarkan juga memperkenalkan produk melalui perencanaan, pelaksanaan dan pengendalian komunikasi persuasif dengan pelanggan. Pelanggan disini adalah ditujukan kepada masyarakat yang akan menjadi bagian anggota juga mitra dari BMT SYAHIDA IKALUIN. Tujuannya pun sama yaitu untuk memperkenalkan produk-produk yang dimiliki BMT SYAHIDA IKALUIN juga untuk membujuk masyarakat agar menjadi bagian dari BMT SYAHIDA IKALUIN dan untuk kelangsungan maju serta berkembangnya BMT SYAHIDA IKALUIN kedepannya.

Strategi promosi BMT SYAHIDA IKALUIN sangat menekankan pada kontennya. Ada pergeseran yang terjadi di BMT bahwasannya dulu BMT SYAHIDA IKALUIN berbasis kepada jenis produk, misalnya produk syariah yg meliputi mudharabah, musyarakah, ijarah, simpanan berjangka juga simpanan wadiah dan lain sebagainya. Melihat situasi sekarang fokus diatas sangatlah sudah tidak relevan, karena apapun medianya yang sebenarkan kita tawarkan itu adalah kebutuhannya mereka (masyarakat), jadi kita menangkap terlebih dulu apa kebutuhannya

${ }^{16}$ Wawancara dengan Supervisor Marketing Bapak Abdul Kodir, S.HI, hari Senin 13 Mei 2019 pukul 15.50 wib. 
mereka, dan setelah tertangkap apa kebutuhannya barulah kita carikan solusinya apakah dengan ijarah, mudharabah, musyakarah, wadiah atau bahkan jual beli ${ }^{17}$.

Kebutuhan disini juga meliputi baik dari masyarakat yang kelebihan dana sehingga bingung bagaimana untuk menyimpannya, juga kepada masyarakat yang membutuhkan dana sehingga dapat terpenuhi kebutuhan-kebutuhan dari masyarakat tersebut. Sesuai dengan pengertian juga fungsi Lembaga Keuangan Syariah itu sendiri yaitu sebagai Lembaga intermediary yang menghimpun dana dari masyarakat yang kelebihan dana dan juga menyalurkan dana kepada masyarakat yang membutuhkan dana.

Maka dapat disimpulakan bahwa strategi yang dilakukan BMT dapat berubahubah setiap zamannya karena berbagai macam penyesuaian. Perubahan-perubahan strategi ini pun tujuannya satu agar BMT SYAHIDA IKALUIN dapat tetap eksis menjalankan usahanya sebagai bagian dari lembaga keuangan syariah. Jadi, strategi promosi yang di pakai oleh BMT SYAHIDA IKALUIN adalah mengidentifikasi kebutuhan masyarakat, berangkat dari kebutuhan masyarakat tersebut dikeluarkanlah produk-produk yang sesuai syariah yang tujuannya untuk memenuhi kebutuhan tersebut.

Dalam hal promosi produk simpanan syahidayang merupakan produk unggulan yang dimiliki BMT SYAHIDA IKALUIN, karyawan terkhusus bagian account officer menjelaskan manfaat serta keunggulan-keunggulan yang dimilki produk simpanan syahida. Karena produk simpanan syahida ini adalah tabungan maka teknik promosinya sangat mudah yaitu hanya dengan mempengaruhi masyarakat untuk mau bahkan gemar menabung karena kegiatan menabung merupakan hal yang paling mudah dilakukan oleh setiap orang, mereka hanya cukup menyisihkan sebagian uang mereka untuk disimpan dalam bentuk tabungan.

Selain teknik promosi produk simpanan syahida, terdapat pula keunggulan dari produk ini, antara lain sebagai berikut:

1) Pro aktif

\footnotetext{
${ }^{17}$ Wawa ncara dengan Manager Operasinal Bapak Ir. Boni Fa isal, hari Jum 'at 03 Mei 2019 pukul 14.50 wib.
} 
Pro aktif (jemput bola), BMT Syahida memberikan pelayanan yaitu marketing mendatangi anggota yang mau menabung sehingga anggota-anggota BMT tidak perlu lagi mengeluarkan biaya untuk datang ke kantor BMT menyetorkan tabungannya. Disini merupakan keunggulan karena tidak semua lembaga keuangan melakukan hal tersebut, banyak Lembaga keuangan yang masih memperhitungkan biaya penjemputan sehingga tidak semuanya memberikan pelayanan seperti yang dilakukan oleh BMT Syahida IKALUIN. Apa yang dilakukan oleh BMT sesuai dengan ayat Al-Qur'an dalam hal berusaha. Bahwa manusia atau kita tidak boleh hanya berdiam diri.

2) Berlandaskan Syariah

BMT Syahida yang berlandaskan syariah mempunyai keunggulan tersendiri jika dibandingkan dengan Lembaga keuangan tanpa landasan syariah, tentu dengan landasan Syariah tersebut tidak ada kekhawatiran sedikitpun bagi nasabah dalam pengelolaan dananya, sehingga mempunyai nilai barokah. Dan nilai barokah ini mempunyai efek motivasi dalam meraih pahala. Jadi di BMT Syahida itu terdapat motivasi lain selain hanya menabung/menyimpan uang saja. Terlepas dari besar atau kecilnya margin yang didapat justru ada nilai lebih dari pada hal itu yaitu anggota lebih merasa tenang, karena ini merupakan lembaga keuangan syariah y ang terbebas dari riba serta akad-akad yag bathil, uangnya walaupun kecil tapi barokah jauh lebih membawa manfaat.

3) Saldo minimal yang ditetapkan BMT Syahida jauh lebih rendah dibandingkan dengan Lembaga Keuangan lainnya

BMT SYAHIDA IKALUIN menetapkan minimal saldo yaitu Rp 50.000,- dan dapat menabung mulai dari Rp 10.000,- . dengan ketentuan ini seharusnya BMT akan lebih banyak mendapatkan anggota karena jauh lebih terjangkau dari Lembaga keuangan lainnya. Islam pun sudah mengatur bahwa kita tidak diperbolehkan untuk berlebih-lebihan.

Jadi, strategi promosi yang digunakan oleh BMT SYAHIDA IKALUIN adalah melalui segmentasi pasar caranya dengan melihat kebutuhan masyarakat, berangkat dari kebutuhan itulah maka BMT mengeluarkan produk-produk yang dapat memenuhi kebutuhan tersebut. Dan strategi promosi produk simpanan syahida adalah dengan cara mempengaruhi masyarakat agar mau dan juga gemar menabung serta memberitahukan 
Manajemen Promosi BMT Syahida Ikaluin Dalam Meningkatkan Keanggotaan Produk Simpanan Syahida

manfaat dari menabung tersebut juga memberitahu keunggulan-keunggulan yang dimiliki oleh produk simpanan syahida.

\section{KESIMPULAN}

Manajemen marketing yang dilakukan oleh BMT SYAHIDA IKALUIN dalam upaya peningkatan jumlah anggota adalah dengan menggunakan bantuan media dalam hal promosi, media yang digunakan berupa web dan instagram serta menggunakan media cetak dan media sosial. BMT SYAHIDA IKALUIN dalam manajemen marketingnya juga memanfaatkan salah satu produk unggulan yang dikeluarkannya dimana produk ini dinilai sangat efektif dalam hal peningkatan jumlah anggota, produk tersebut adalah produk simpanan syahida. Produk simpanan syahida merupakan suatu produk yang dikeluarkan BMT untuk mengajak masyarakat agar gemar menabung, produk ini sejenis simpanan dengan menggunakan akad wadiah. Alasan produk ini menjadi produk unggulan adalah karena setoran minimal $\mathrm{Rp} 10.000$,- untuk ditabungkan.

Strategi promosi produk simpanan syahida melalui karyawan terkhusus bagian account officer menjelaskan manfaat serta keunggulan-keunggulan yang dimilki produk simpanan syahida. Karena produk simpanan syahida ini adalah tabungan maka Teknik promosinya sangat mudah yaitu hanya dengan mempengaruhi masyarakat agar mau dan gemar menabung karena kegiatan menabung merupakan hal yang paling mudah dilakukan oleh setiap orang.

\section{DAFTAR PUSTAKA (BIBLIOGRAPHY)}

Al-Arif, M.N.R. 2011.Dasar-dasar Ekonomi Islam. Surakarta: Era Adicitra Intermedia. Ali, L.dkk. 1997. Kamus Besar Bahasa Indonesia.Jakarta : Balai Pustaka.

Alma, B. 2002. Manajemen dan Pemasaran Jasa. Bandungc: Alfhabetha.

Aziz, M.A. 2004. Pedoman Pendirian Baitul Mal wa Tamwil. Jakarta: Pinbuk Parcel.

Dani, I. 1999. Bagaimana Memperbaiki Pemasaran Usaha Anda. Jakarta: Freidreih Ebert Stiftung.

Dzajuli, A. \& Janwari, Y. 2002.Lembaga-lembaga Perekonomian Umat. Jakarta: PT Raja Grafindo.

Hasan, N.I. 2014.Perbankan Syariah (Sebuah Pengantar). Ciputat: GP Press Group. 
Manajemen Promosi BMT Syahida Ikaluin Dalam Meningkatkan Keanggotaan Produk Simpanan Syahida

Huda, N.\& Haykal, M.2010. Lembaga Keuangan Islam: Tinjauan Teoritis dan Praktis. Jakarta:Kencana.

Hunger, D. \& Wheelen, T. 2003.Manajemen Strategis. Yogyakarta: Penerbit

Karim, A.A. 2004.Bank Islam: Analisis Fiqih dan Keuangan. jakarta: Raja grafindo persada.

Kotler, P. 1996.Marketing Manajemen: Analisis, Planning, Implementasi dan Kontrol. Jakarta: Erlangga.

Marno. \&Supriyanto, T. 2008.Manajemen dan Kepemimpinan Pendidikan Islam. Bandung: PT Reflika Aditama.

Muhammad. 2002. Manajemen Bank Syariah. Yogyakarta: UPP AMP YKPN. 61

Ridwan, A.H. 2013.Manajemen Baitul Mal wa Tamwil. Jakarta: CV Pustaka Setia.

Soemitra, A. 2016.Bank \& Lembaga Keuangan Syariah. Jakarta: Kencana.

Swasta, B. 1998. Azas-azas Marketing. Yogyakarta: Erlangga.

Syafaruddin. 2015.Manajemen Lembaga Pendidikan Islam. Jakarta: Ciputat Press.

Syakir, A. 2015. Perbankan Syariah. Medan: UIN-SU.

Tjiptono, F. 2002. Strategi Pemasaran. Yogyakarta: Andi.

Winardi. 1993.Asas-asas Manajemen. Bandung: Alumni.

Yusanto, M.I \& Widjajakusuma, M.K. 2002. Mengagas Bisnis Islami. Jakarta : Gema Insani Press. 